TEME, г. XLI, бр. 1, јануар-март 2017, стр. 55-70

Оригинални научни рад

DOI: $10.22190 /$ TEME1701055J

Примљено: 10. 07. 2016.

UDK 811.163.41'367.622.22

Одобрено за штампу: 17. 01. 2017.

\title{
АСОЦИЈАТИВНИ ПРИСТУП ЛЕКСИКАЛИЗОВАНИМ ИМЕНИЧКИМ ДЕМИНУТИВИМА СА СУФИКСОМ -ИЦА КОД СТУДЕНАТА СРБИСТИКЕ
}

\author{
Александра А. Јанић \\ Универзитет у Нишу, Филозофски факултет, Департман за српски језик, \\ Ниш, Србија \\ aleksandra.janic@filfak.ni.ac.rs
}

\begin{abstract}
Апстракт
Предмет овог рада су лексикализовани именички деминутиви изведени суфиксом -ица у српском језику, посматрани когнитивнолингвистички, кроз асоцијације матерњих говорника, и то студената Србистике. Циљ нам је да на основу првих асоцијација испитаника утврдимо код којих се то деминутивних именичких облика који имају бар једно лексикализовано значење доминантно јављају асоцијације управо повезане са неким лексикализованим значењем (нпр. бабица, иколице), а не деминутивним (нпр. бубица, пахуљище). Добијене резултате посматрамо у односу на сам облик (нпр. једнина или множина) и сферу употребе, те на степен лексикализованости (потпуна или делимична лексикализација). Закључци доприносе јаснијој перцепцији лексикализованих деминутива, а корисни су и из лексикографског угла обраде одредница, те разврставања значења.
\end{abstract}

Кључне речи: именички деминутиви, суфикс -ица, лексикализација, асоцијације, српски језик.

\section{ASSOCIATIVE APPROACH TO LEXICALIZED NOUN \\ DIMINUTIVES WITH THE DERIVATIONAL SUFFIX -ICA \\ FROM THE PERSPECTIVE OF THE STUDENTS OF THE SERBIAN LANGUAGE AND LITERATURE}

\begin{abstract}
The subject of this paper are the lexicalized noun diminutives with the Serbian derivational suffix -ica from the perspective of cognitive linguistics, regarding associations Serbian native speakers (students of the Serbian language and literature) had to them. Our aim is to determine which of the lexemes given in the questionnaire as stimuli and first associations provided by the participants are mainly connected with a lexicalized meaning (e.g. babica, školice), and not with the diminutive one (e.g. bubica, pahuljice). The results of the analysis of the noun diminutives with at least one lexicalized meaning are analyzed regarding their form (singular/plural), usage, and the degree of the lexicalization (complete or partial lexicalization). The conlusions are
\end{abstract}


useful for the clearer perception of the lexicalized diminutives, the lexicographical point of view, and for the distribution of meaning as well.

Key words: noun diminutives, derivational suffix -ica, lexicalization, association, Serbian language.

\section{УВОД}

У овом раду се анализирају лексикализовани именички деминутиви изведени суфиксом -ица у српском језику, једним од најпродуктивнијих, при чему се грађа посматра с обзиром на прву асоцијацију матерњих говорника, конкретно студената Србистике. Ради се о томе да се лексикализовани именички деминутиви у раду тако супротстављају нелексикализованом облику, односно оном са умањеним (и/или хипокористичким) значењем.

Когнитивнолингвистички, циљ нам је да на основу првих асоцијација матерњих говорника утврдимо код којих се деминутивних именичких облика који имају бар једно лексикализовано значење доминантно јављају асоцијације повезане са неким лексикализованим значењем удаљивши се тако од основног појма (мотивне речи), што даје допринос и лексикографској обради ове групе именица и њихових значења. Кључна је перцепција деминутивних облика са бар једним лексикализованим значењем од стране матерњих говорника, односно статус лексикализација и разлике међу њима у садашњем тренутку. Резултате ћемо посматрати и у односу на степен лексикализованости - потпуна или делимична, у зависности од тога да ли лексема има терминолошки статус или не (в. Јанић, 2013а). Овај рад представља и својеврсни додатак Асоиијативном речнику српскога језика (Пипер и др., 2005), у коме није било оваквих именица као стимулуса.

У другом одељку рада наводимо досадашња истраживања која ће нам бити од значаја у самом раду, затим у трећем кроз детаљну анализу сагледавамо резултате асоцијативног упитника на лексикализоване именичке деминутиве са суфиксом -ища, поредећи их притом и према степену лексикализованости. Четврти одељак садржи закључке рада.

\section{ДОСАДАШЊА ИСТРАЖИВАЬА}

Деминутиви су „морфолошка категорија која примарно денотира умањење, међутим, из тога израњају вишедимензионалне модификације” (Грицкат, 1995, стр. 1), а лексикализаиија је „pretvaranje nekog leksičkog elementa (morfeme i dr.) ili spoja, grupe leksičkih elemenata u jedan kompaktni jezički element koji ima funkciju zasebne reči” (Реco-Stanojčić, 1972, str. 200). Другим речима, лексикализација је 
„semantički proces kojim od oblika riječi i leksičkih skupina nastaju nove leksičke jedinice kojima se popunjava leksički fond" (Tafra, 2005, str. 115).

Пишући о деминутивима, а у вези са лексикализацијама, Радмила Ђурић издваја да „mnogi deminutivni oblici predstavljaju idiomatizovane lekseme, samo formalno u vezi sa deminutivima" (Đurić, 2006, str. 159), при чему наглашава две појаве: потпуно довршену лексикализацију, често са прелазима ка терминологији, и делимичну лексикализацију, код које се деминутивност ипак осећа. Оваква подела постоји и у раду Ирене Грицкат (1995, стр. 8). При упоређивању резултата асоцијативног упитника са степеном лексикализованости користићемо трочлану поделу лексикализованих деминутива према степену лексикализованости и према томе шта означавају (в. Јанић, 2013a): (1) потпуна лексикализација са терминолошким статусом, тј. са статусом техничког термина; (2) потпуна лексикализација без терминолошког статуса, тј. без статуса техничког термина; (3) делимична, слаба лексикализација, без терминолошког статуса. Истичемо и то да у наведеној подели лексикализованих деминутива граница није чврста.

Четири могућности тумачења секундарних значења примера типа ручица издваја Рајна Драгићевић (2016, стр. 458). Једно наведено решење је хомонимични однос, друго увођење два различита суфикса (-ица $a^{1}$ и -ица $a^{2}$, засебно се посматра деминутивни и предметни суфикс -ица), што поново упућује на хомонимију, и нећемо их детаљније коментарисати будући да механизам метафоре сматрамо условом за лексикализацију. Мишљење Рајне Драгићевић (четврто које наводи) јесте да „сви параметри показују јаку семантичку везу између ова два значења [лексикализованог и нелексикализованог, деминутивног] и условљеност секундарног значења примарним" (Драгићевић 2016, стр. 458). Поменуто објашњење не видимо нужно као супротстављено трећем схватању које се наводи, конкретно када постоји самосталност у односу на примарно, деминутивно значење (када се у њему потпуно изгубила деминутивна нијанса). Сматрамо да метафора и полисемија свакако јесу у основи лексикализације именичких деминутива, те да се на основу степена лексикализованости може утврдити тренутни статус свих постојећих лексикализација именичких деминутива, поготово асоцијативном методом, коју ћемо у наставку користити ради доношења конкретнијих закључака.

Деминутивима и лексикализацијама бавили су се и: Клајн (2003), Радић (1997), Хохенхаус (Hohenhaus, 2005), Макишова (2006), Драгићевић (2008), Јовановић (2010), Јанић (2012; 2013б), а издвајамо и монографију Рајне Драгићевић (2010) посвећену вербалним асоцијацијама кроз српски језик и културу. 


\section{РЕЗУЛТАТИ АСОЦИЈАТИВНОГ УПИТНИКА ЗА ЛЕКСИКАЛИЗОВАНЕ ИМЕНИЧКЕ ДЕМИНУТИВЕ СА СУФИКСОМ -ИЦА}

У наставку наводимо резултате упитника који је подразумевао да испитаници, ${ }^{1}$ матерњи говорници српскога језика, за сваки задати именички деминутивни облик са суфиксом -ица (који поред деминутивног има и бар једно лексикализовано значење) напишу прву асоцијацију у виду речи, синтагме или реченице. Уколико је асоцијација изостала, испитаници су остављали празнину или писали косу црту. Као и у самом упитнику, азбучним редом наводимо све примере из упитника: бабища, бојица, бомбица, бубица, водица, глиница, гљивище, жабииа, звездица, јабучица, јагодииа, јелкица, картииа, кесииุ, књижица, кобилица, козице, колица, корпице, кошуљиияа, крпице, круница, лепезица, лопатица, марамица, оградища, папучица, пахуsице, плочииа, погачииа, постељииа, пушкииа, ресица, свећица, стрелица, теткица, чашица, четкица, школице. Примери су ексцерпирани из Обратног речника (Николић, 2000), а значења смо проверавали у речницима српског језика (нпр. Николић, 2007).

Детаљније се бавимо онима који доминантно имају јед(и)но лексикализовано значење као прву асоцијацију будући да се подразумева да могу имати и деминутивно значење, те смо у овом раду искључили примере код којих је у упитнику као прва асоцијација доминирало деминутивно, односно нелексикализовано значење: бубииа, глиница, жабииа, звездица, јелкица, кесица, кобилица, козице, ле-

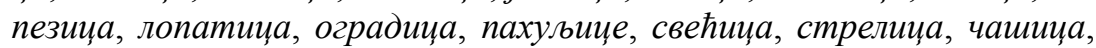
четкий.

\section{Лексеме стимулуси без икакве асоиијаиије}

Празно поље остављано је код скоро три четвртине речи бар једном, а од анализираних лексема без асоцијација су код неких испитаника били: постељица (7), ресица (3), теткица (2), бомбица, водица, гљивице, јагодииа, корпице, кошуљица, крпиче, круница, марамица, папучища, плочица (по 1). Међу њима није било лексикализованих значења непознатих испитаницима, али се изостанком асоцијације самим тим нису определили ни за деминутивна/хипокористична значења.

\footnotetext{
${ }^{1}$ Испитаници су били студенти треће године Србистике Филозофског факултета Универзитета у Нишу у школској 2013/14. Укупно педесеторо ових матерњих говорника српског језика попунило је упитнике у марту 2014. године, и то пре обраде деминутива у оквиру области творбе речи и уопште пре увођења појма лексикализације. Још једном им захваљујемо на сарадњи.
} 


\section{Асоиијаџије у корист доминантно лексикализоване употребе}

Код лексеме бабица потврдило се очекивање доминантно лексикализованог значења, што бележе и речници српскога језика стављајући га на прво место. Асоцијације ${ }^{2}$ које несумњиво потврђују доминантност лексикализоване употребе тичу се саме професије: жена која помаже при порођају (4), жена која порађа, жена која обавља порођај, акушерска сестра, гинеколог, медищина; места рада: болница; као и конкретног описа посла - порађања жене и доношење детета на свет: порођај (15), беба (12), дете (7). Са друге стране су изоловани примери (2 од 50) који потврђују да и нелексикализовано (деминутивно/хипокористично) значење може матерњим говорницима српскога језика бити прва асоцијација: баба, мала баба. Асоцијације попут жена, једва чекам, руке, Данило издвојили смо због недовољних разлога да их сврстамо у оне које се тичу лексикализованих или нелексикализованих значења. На пример, хипероним хипонима бабица у значењу „акушерка” и у деминутивном/хипокористичном значењу је жена; бабица порађа рукама, али истовремено се и за баку везује осећање велике љубави, грљење и сл. Тако се и реченица Једва чекам може повезати са скорашњим сусретом са баком или ишчекивањем нечијег порођаја, док би се властито име могло односити на неко дете, будући да се не ради о женском имену. С друге стране, акушерство не искључује мушкарце.

Потпуна лексикализација облика бојица видљива је у томе што се његова употреба не повезује директно са речима са којима је творбено у вези (бојити, па ни са именицом боја), већ са спецификованим значењем средства за цртање: дрвена (9), дрвене боје (2), оловка (6), дрвена оловка у боји, ликовна оловка у боји, темпера, крејон, воштана, воштана боја; затим са самом радњом цртања: иртање (2), иртеж (7), пејзаж, слика, бојанка (4), папир, ликовно (2), култура; као и са типичним сценариом - дете је оно које црта, најчешће у вртићу или у нижим разредима основне школе: дете (3), вртић (2), детињство, предиколско, први разред.

Готово потпуна лексикализација деминутивног облика бомбица се у употреби уочава на основу првих асоцијација које се односе на врсту колача лоптастог облика: колач (20), колачи, чоколадни колач (2), чоколадни колач у облику куглице, чоколадна бомбииа, слаткиш (4), бомбона; на његове важније састојке или особине: чоколадна (3), слатка, чоколада (4), кекс, кокос; или пак на место где се може купити или јести: посластичара. Са друге стране је нелексикализо-

\footnotetext{
${ }^{2}$ Асоцијације наведене у упитнику преносимо онако како су их написали испитаници, без икаквих измена. Бројеви у загради односе се на број понављања. Уколико се нека асоцијација јавила једанпут, број не пишемо.
} 
вана употреба, која се односи на мале бомбе, ратно стање и сл.: pam, Ал-каида, мало, мала бомба, ручна, муниција; или пак на деминутивно значење сличних облика у различитим сферама употребе: лоптица, дискотека.

Доминантно је лексикализована употреба облика водица, што се наслућује из синтагме у којој се најчешће и употребљава (светена водица), као и из тога што се у речницима управо то значење прво наводи (в. Николић 2007), а не деминутивно: света (14), ирква (4), света водица (3), светена (2), критење, манастир, свештеник, вода која има неко благотворно дејство, Богојављење (2); или уопште вода са специфичним карактеристикама: пиринчана, светена/иећерна, слатка, уста (мисли се на испирање уста). На мотивну реч вода, изразе у вези са њом и на деминутивно значење упућују следеће асоцијације: вода (2), извор (3), бара, деминутив од речи вода, длан (повезује се са поређењем као мало воде на длану), мала бара, мала вода, мало воде, поток, „Роса”, флашица 0,5 л воде, чесма (односи се на воду са чесме). За асоцијацију плод претпостављамо да се такође повезује са нелексикализованим значењем тиме што је за његов развој неопходна вода.

Велики степен лексикализованости облика гљивище, маркираног и множином, види се у већини асоцијација, које показују доминантну лексикализовану употребу. Најчешће се повезује са гљивичном инфекцијом на ноктима стопала: болест (6), болести, обољење (4), кожно обољење, инфекиија (3), бактерије (2), гљивице које се налазе у нашем организму, полна болест, гинеколог, упала, у грлу, кожна болест (2), кожа, ноге (2), нога, стопала (2), стопало (2), нокат, нокти, прљавштина; или на биљкама: купус. На мотивну реч и нелексикализовано значење недвосмислено упућују: печурке (7), печурка (2), nањ, алге, а двосмислени могу бити биологија, влажно место.

Асоцијације на деминутивни облик јабучица биле су доминантно повезане са неким од његових лексикализованих значења. У већини случајева радило се о грлу, односно о Адамовој јабучици: Адам (5), Адамова (3), Адамова јабучииа (3), грло (5), врат, која је изражена код мушкараца, па отуда и такве асоцијације: мушкараи (2), момак. У неким случајевима матерњим говорницима српског језика прва асоцијација била је очна јабучица, односно: око (4), очна (2); или пак синонимно значење лексикализацији јагодице (на врховима прстију): прст, затим (на лицу): кост, али и образ (2), лице, те индиректно с тим у вези смех. Дешавало се и да испитаници не спецификују на који део тела мисле, већ искористе хиперонимски израз део тела (2), али је и тада јасно да су на уму имали лексикализовано значење с обзиром на различиту архисему. Нелексикализовано значење видљиво је у свим асоцијацијама у којима се помиње воће (3), јабука, деминутивно мала јабука (2), дрво, зелено. Израз Адамова јабука ни- 
смо везали за лексикализовано значење будући да такав израз није идиоматизован у српском језику, већ упућује на посесивност и примарно значење лексеме јабука. Индиректно, са поменутом лексемом и њеним нелексикализованим значењем доводили су се у везу епска песма, живот, Снежана и седам патуљака, али и име које за мотивну реч има поменуту заједничку именицу: Јабучило.

Лексема јагодица доминантно се везује за лексикализована значења, било да се ради о делу лица или врховима прстију. Будући да је међу децом актуелан цртани филм „Јагодица Бобица”, оним испитаницима који су у контакту са децом и емисијама за децу као асоцијација падао је на памет иртани или Бобииа (по једном су се јавиле ове асоцијације). Хиперонимска синтагма део тела јавила се једанпут као асоцијација, насупрот синтагми део лица (2). На део лица недвосмислено се односе: образ (6), образи, образи и уста, јагодица на лииу, лице, део испод ока на човечјем лииу, а посредно и смех. Будући да румене јагодице представљају идеал лепоте у лирским песмама, отуда објашњење за асоцијације лирска песма и лепа жена. На врх прста упућују асоцијације у виду поменуте именице у облицима номинатива једнине и множине, као и генитива једнине (прст (3), прсти, прста), синтагма јагодица прста, и уско са њом повезана именица нокат. Из асоцијација које маркирају нелексикализовано значење можемо доћи до концепта појма јагодица - бобичасто воће које се може јести са шлагом или пити као сок, а сазрева крајем пролећа и може расти у у шуми или винограду (бобица (11), воће, воћка, јагода, шлаг, шумска јагода, сок, пролеће, виноград). Као немотивисане и недискриминаторне да бисмо се определили да ли се односе на лексикализовано или нелексикализовано значење издвајамо асоцијације у виду придева ирвен (у облицима ирвено (2), црвена) и хомонимичне именице град (насељено место) и град (временска непогода), те се без акцента или контекста не може утврдити о којој именици се ради.

Асоцијације на лексему картица доминантно упућују на лексикализована значења у смислу легитимације, а не мале карте: за мензу (7), картица за мензу, менза, ручак, пропусница, библиотека (3). Честе су и асоцијације у вези са платним картицама, чије је значење такође лексикализовано, будући да се ради о пластифицираним картицама са посебним карактеристикама и будући да у том значењу није могуће користити синтагму платна карта, што такође показује лексикализованост: банка (4), новаи (4), кеш (антоним у смислу плаћања готовином или картицом), кредитна (5), кредит (3), платна (2), платна картица, банкомат (3). Још једна лексикализована употреба присутна је у синтагмама попут меморијска картиия, споју СИМкартища и сл., у којима деминутивни облик такође није могуће заменити основним. У вези са тим су асоцијације: мобилни (3), меморија, 
$С И М$, али и оне које се користе у друштвеним играма попут „Монопола", те отуда асоцијација друштвена игра. Будући да се облик картица може заменити обликом карта у спојевима попут аутобуска картица/карта без промене у значењу, такве облике нисмо сматрали лексикализованим деминутивима јер се деминутив не диференцира по значењу у односу на основни облик. На нелексикализована значења упућивале су следеће асоцијације: аутобус (2), воз, картица за аутобус, месеи, месечна карта, превозни градски саобраћај.

Лексема књижица као стимулус резултирала је бројним асоцијацијама у корист лексикализованих значења, било да се односе на здравствену књижсиу (здравствена (8), здравствена књижииа (3), болница, Дом здравља, здравље, здравствено осигурање), ђачку (Ђачка кьижица (2), Ђачка (8), Ђак (4), школа, школска, индекс (2), оцена (2), оцене (2)), радну или штедну (рад, уштеђевина). Са друге стране су малобројне асоцијације које недвосмислено упућују на нелексикализовано значење: књига, мала књига, књига од стотинак страна, цепна, Мали прини, сликовница, а неке су у истом семантичком пољу и притом се не могу довести у везу ни са једним од лексикализованих значења: свеска, писати, љубав. Асоцијација корище може се довести у везу и са ђачком књижицом или индексом, будући да имају изражене корице, често тврдог повеза, за разлику од здравстене књижице, на пример.

Асоцијације на лексему колица у највећој мери упућују на лексикализовано значење, било да се ради о колицима за бебу, о грађевинским колицима или пак о колицима у самопослузи: беба (20), дете (8), бебе (2), колица за бебе, новорођенче, дечја (2), дечија (2), дечија колица, шетање, за бебе или у маркету, рад (2), ручна колица (2), грађевина, грађевинска, песак, терет. Деминутивно/хипокористично значење није показано у синтагматском споју, већ су се колица или доводила у везу са основним обликом (кола) или је пак асоцијација била кеш, повезана са жаргоном. Асоцијацију радити нешто као врло уопштену нисмо сврстали ни у оне асоцијације које упућују на лексикализована, ни у оне које упућују на нелексикализована значења.

Међу асоцијацијама на лексему корпице преовладавају оне повезане са лексикализованим значењем, било да се односи на врсту колача или на украсни папирни држач за колаче: колачи (9), колач (6), колача, колачи Чоколадне корпище, чоколадне, бомбиче, мафини, за колаче (3), за бомбице, папирне у које се стављају колачи, украсне, украси, шарене. Још једно лексикализовано значење везује се за украс на коси помоћу ког се прави пунђа, те се у том случају не може заменити обликом корпа за косу (асоцијација за косу). Нелексикализовано значење доводи се у везу са (малим) корпама за воће, поврће, јагоде, (ускршња) јаја, хлеб или се односи на украсне корпе за цвеће: 
цвеће (3), јагоде (3), воће (2), деца, дрвене, јагода, јаја, јаја - Ускрс, купине, мале корпе, пикник, поврће, хлеб. Асоцијацију корпе за брусхалтер сврставамо у нелексикализовану употребу. Исто смо учинили и са асоцијацијом продавница, јер се у продавници често користи корпа.

По броју су готово изједначене асоцијације у корист лексикализованог и нелексикализованог значења лексеме кошуљииа, а нешто више има оних првих: змија (20), змијска (2), змијина, змијска кошуљииа, кожа коју змија мења, смук, плацента. Са друге стране, на нелексикализовано, деминутивно (и хипокористично) значење упућују следеће разноврсније асоцијације: одећа (2), беба, бела (2), бела боја, град, дете, дечак, лутка (2), карирана, кошуља за деиу, кравата, мала кошуља, мало дете у кошуљи, одевна комбиначија, одевни предмет за деиу, плава, пролеће, рођење детета, свила. Кошуља се као одевни предмет често везује за белу боју, носи се уз кравату кад се иде у град, може бити и карирана или направљена од свиле. Мале кошуље носе деца и лутке, а постоји и обичај цепања кошуље оцу кад му се роди дете (с тим што се асоцијација у вези са рођењем детета може довести у везу са плацентом, лексикализованим значењем).

Скоро све асоцијације на лексему крпице доводе се у везу са лексикализованим значењем и односе се на одећу: одећа (8), куповина (4), гардероба (3), коса (3), лутка (3), лутке (3), мода (3), Васко Попа (2), „Врати ми моје крпице”, за косу (2), ствари (2), барбика, данашьи назив за одећу, девојка, девојке, делови одеће, жена, лирска песма, локне, локнице, луткище, поцепано, стварчице, стварчище за барбику, увијање косе, шопинг. Напомињемо да постоји семантичка разлика у употреби недеминутивног/основног и деминутивног лексикализованог облика (крпе/крпище) када се односе на одећу. Прво је негативно конотирано, а друго или није или је пак позитивно конотирано. Од већ поменутих асоцијација издвајамо и оне које би се могле повезати са нелексикализованим значењем: поцепано и жена, будући да се крпе могу поцепати, а жене су те за које се најчешће везују различити послови у кући.

Међу асоцијацијама на лексему круница највише има оних које се односе на њена два лексикализована значења (део зуба или цвета): зуб (12), зуби (3), круница зуба (2), цвет (13), део извета. Са нелексикализованим значењем доводе се у везу асоцијације које се односе на основни појам, с тим у вези на краљевске титуле, или пак на свет бајки и, у пренесеном значењу, на победу: круна (2), мала круна, краљииа (5), принцеза (4), краљ, барбика (3), победа, бајка.

Асоцијације на стимулус марамища везују се за лексикализована значења у сфери медицине, односно за плућну, трбушну и срчану марамицу: плућа (8), плућна (3), плућна марамица, трбух, срие. Са друге стране, ту су и асоцијације које упућују на лексикализовано 
значење у виду папирнате марамице, а не у значењу „мала марама”: нос (8), марамица за брисање носа, прехлада (3), папирна (4), папирната, папир (2), папирна марамица (3), па и влажна (2), али напомињемо да је лексикализовано значење у последњем примеру само када се односи на посебну врсту марамица, ону папирнату, не и онда када се ради о малој марами која је наквашена. На нелексикализовано значење упућују асоцијације марама и свила, а асоцијације бака, бело, брисање, кијање, коло, крв, меко, плач, сузе нећемо експлицитно придружити ни првој ни другој групи будући да би се семантички могле повезати са обема.

Више асоцијација на лексему папучииа било је за лексикализовану, а нешто мање за нелексикализовану употребу. У првој групи су оне асоцијације које упућују на део неке машине у најширем смислу те речи, почев од аутомобила, па све до инструмената попут клавира: ауто (5), аутомобил (5), гас (6), за гас (2), за гас и квачило у колима, у колима (гас, квачило, кочница), квачило, команде у аутомобилу: папучица за гас, папуча код машине за шивење, машина, клавир, бубањ. У групи асоцијација које се доводе у везу са нелексикализованим значењем су: мала папуча (3), Пепељуга (3), обућа (2), соба (2), собна, вече, дете, дечко, кломпе, лепо, лето, мало стопало, мача, мачка, папуча, принцеза. Асоцијацију реч нисмо узели у обзир будући да се због своје општости може повезати са оба значења.

Бројне и разноврсне су асоцијације на лексему плочица које упућују на неко њено лексикализовано значење, што је показатељ честе лексикализоване употребе ове именице. Испитаници су најчешће мислили на плочице у купатилу (купатило (23), у купатилу (2), плочице у купатилу, плоча за купатило, WC, зид, керамика, клизаво), а неочекивана асоцијација је у виду споја плоча за купатило, уместо плочица/плочице за купатило. Затим следе асоцијације које упућују на плочице на стомаку које се добијају након напорног вежбања (стомак (2), трбух, трбушњаци (3)), или се пак односе на привезак (2) или таблииу на којој је написано нечије име (асоцијације с тим у вези су: име, име и презиме), а доводили су се у везу и са „флором”, хокејом, крвљу и сл.: ирна плочица за жаљење умрлог, крв, лан, хокеј. На нелексикализовано, односно деминутивно значење упућују следеће асоцијације: мала плоча, мала плоча од метала, сто, ипер плоча.

За именице које имају исту архисему код лексикализованог и нелексикализованог значења теже је одредити које су се асоцијације односиле на једну, а које на другу употребу, будући да се могу повезати са обе. Из тог разлога, међу асоцијацијама на лексему погачица које више упућују на лексикализовано значење издвајамо: пециво (11), доручак (2), топло - меко, ужина, Житопек, лисната, са сиром; а међу оне повезане са нелексикализованим: хлеб (6), Бадње вече, 
Божић, слава (2), мала погача (2), погача. На крају издвајамо оне асоцијације које би се семантички могле повезати са обема групама: пекара (5), сир (4), сусам (2), храна (2), бака, за јело, јело, мама, миpuc. Делимично немотивисаном сматрамо асоцијацију око.

Међу асоцијацијама на лексему постељиия већи је број оних које недвосмислено упућују на лексикализовано значење, односно оних које се на различите начине доводе у везу са трудноћом и порођајем: порођај (8), материца (2), биологија, део материще у којој се развија беба, део органа, мајка, жена, трудна жена, трудница, трудноћа, младунче, плачента, животиьска плацента, крава, крв. На нелексикализовано значење недвосмислено упућују асоцијације постеља за бебу, мала постељь, чаршав, кревет (7), спавање (2), док се беба (6) и дете (2) могу припојити и једном и другом, будући да се беба (мало дете) у мајчиној утроби развија помоћу постељице, а када се роди спава у кревету у својој постељици.

Према асоцијацијама, висок степен лексикализованости појављује се у облику пушкица. ${ }^{3}$ Тако испитаници под пушкицом првенствено подразумевају папирић за преписивање, а не малу пушку, што се може видети у следећим првим асоцијацијама и њиховој фреквентности: преписивање (19), за преписивање (4), испит (3), колоквијум/контролни, контролни, папир, папирић, папирић за преписиваюе (2), превара, преписивати, студент, факултет. На нелексикализовано значење упућују асоцијације попут лов, мала пушка, оружје, метак (2), док се асоцијације играчка (4), дечак (3), дете, играчка за деиу доводе у везу са играчком која изгледа као мала пушка, при чему није променила своју основну функцију (могућност пуцања), те је у том смислу не сматрамо правом лексикализацијом, попут односа aуmo-aymuћ, где се у лексикализованом облику деминутива губи могућност вожења тог малог аутомобила тако што би неко сео у њега.

Асоцијације на лексему ресица већим делом односиле су се на лексикализовано значење (ресицу у грлу, ресицу уха, црева): грло (10), у грлу, уста (3), у усној дупљи, зуби (2), језик, испод језика, душник, ждрело, кашаљ, уво (6), ухо (3), око, очи, црево, трепавице. Нелексикализовано значење односи се на мале ресе које се могу наћи на различитим одевним предметима, отуда: мајища (2), панталоне, ташна, тепих (2), на тепиху, завеса, на завеси, јакна. Посебно издвајамо асоцијације које би се могле односити на оба значења: ирвена (боја ресице у грлу, а могла би се повезати и с неким одевним предметом са црвеним ресама), нож као асоцијација може бити у вези са операцијом (крајника) или пак са сечењем рес(иц)а.

\footnotetext{
${ }^{3}$ Фреквентност лексикализованог значења могла би се оправдати тиме што сами испитаници припадају млађој/студентској популацији. Међутим, у случају облика бубица ни то није било пресудно, већ је доминантно било деминутивно значење.
} 
На основу асоцијација на лексему теткица потврђује се високи степен лексикализованости и таква његова доминантна употреба. То се види из асоцијација повезаних са занимањем: чистачщиа (10), чистачица на факултету или у школи, чистачица у школи (2), чистачице у школи, школа (9), у школи, основна школа (3), помоћ у раду (2), радник, ходник, домар, крпа, шалтер. Недвосмислено нелексикализовано значење показују асоцијације: тетка (3), моја тетка, рођака (2), рођак, нећак и пород, стармала, док двосмислене могу бити асоцијације попут драга особа, жена, кафа, медищина, смешно, будући да у различитим контекстима могу бити везане за лексикализовано или нелексикализовано значење.

За облик школище доминантно се везује лексикализовано значење, оно које се односи на игру на спојеним квадратима нацртаним кредом на бетону, отуда је и лексикализација у облику множине: игра (26), дечја игра (4), дечија игра, игра из детиюства, игрица (2), игрииа за деиу, кочке, креда и игра, скакање, бетон, игралиште, двориште. Ова игра првенствено се везује за девојчице (девојчица, девојчице) или децу уопште и период безбрижности: дете, детињство, деu са лексикализованим, већ и са деминутивним значењем, као и несумњиво: школа (2), основна школа, установа (предшколско).

Анализиране примере поредимо са трочланом поделом према степену лексикализованости (в. Јанић 2013а). Тамо су у првој групи биле именице које карактерише потпуна лексикализација са терминолошким статусом, у којима је процес лексикализације потпуно довршен. Из тог разлога, у таквом лексикализованом значењу не осећа се деминутивност, а те су речи постале термини у одређеним наукама и дисциплинама: медицини, биологији, технологији и сл. ${ }^{4}$ (в. Јанић 2013а, стр. 369): бабица, гљивиче, жабица, јабучица, јагодица, козице, круница, лопатица, марамича, постељица, ресица, чашица; у техници: бубица, жабица, папучица, свећица, четкища; у биологији: жабица, кобилица, круница, козица/-е, кошуљица. ${ }^{5}$ Ови резултати показују да ни код термина прва асоцијација неће увек бити у вези са њима.

У другој групи су лексеме код којих је узвршена потпуна лексикализација, али немају терминолошки статус (в. Јанић 2013а, стр. 370). Овој граничној групи прикључене су оне лексеме блиске тер-

\footnotetext{
${ }^{4}$ Ван тих области, у наведеним облицима осетиће се деминутивност, нпр. у односу марама-марамица, а у медицини само плућна, трбушна, срчана марамииа, без нијансе деминутивности.

${ }^{5}$ Подвучене лексеме су оне које се, према резултатима наше анкете, код матерњих говорника српског језика прве доводе у везу са лексикализованим значењем.
} 
минима које не припадају одређеној научној области или дисциплини, већ другим сферама живота, при чему је и у њима лексикализација потпуна. Као примере издвајамо: бомбиче, колица, погачища, стрелица, иколище (у значењу: врста дечје игре).

Трећу групу чине делимично лексикализовани деминутиви, попут: жабииа, књижсияа, пахуљиие, корпище.

Када се пореде степен лексикализованости и прве асоцијације матерњих говорника, заиста постоји тенденција да код потпуно лексикализованих деминутива прва асоцијација буде у вези са лексикализованим значењем. Оно што још доприноси томе је честа употреба у лексикализованом значењу, у синтагми или ван ње (нпр. здравствена књижица, радна књижииа, штедна књижица). Горенаведене неподвучене лексеме асоцијативно показују тенденцију ка основном, деминутивном значењу, односно таквој њиховој употреби.

Код матерњих говорника свест о лексикализованости именичких деминутива и те како је изграђена и не варира пуно. Ради се о томе да је проценат остварене лексикализоване употребе на нивоу реченица које су смишљали испитаници и онда када су писали прве асоцијације на лексеме-стимулусе заправо приближан (уп. са Јанић 2013б).

На крају, поређења ради, издвајамо и примере именичких деминутива за које Рајна Драгићевић (2016, стр. 460), тим редом, наводи да у речницима стоји да им је основно значење деминутивно, а анкета коју је спровела показује да се деминутивност изгубила: воЂица, гљивице, глинииа, госпођица, девојчица, јаслице, странииа, језичак, прашак, сталак, чунак, чланак, бубаи, дворач, зубач, каменач, колаи, креветаи, маслаи, образаи, палаи, рукавач, синоваи, стубаи, хлебаи, корице, непче, ножице, речиа, ушииа, говече, живинче, клупче, вртић, зупчић, новчић, сестрић, кћерка.

\section{ЗАКЉУЧАК}

У овом раду смо се именичким деминутивима са суфиксом ица који имају бар једно лексикализовано значење бавили из перспективе првих асоцијација које на њих имају матерњи говорници српског језика, студенти Србистике. На овај начин смо лексеме-стимулусе поделили на основу тога да ли доминантно асоцирају на лексикализовано или нелексикализовано значење. У првом случају, ради се о примерима којима смо се и бавили, попут бабица, бојица, бомбица, водица, гљивиче, јабучииа, јагодица, картица, књижица, колица, корпице, кошуљииа, крпице, круница, марамица, папучица, плочища, погачица, постељьияа, пушкиия, ресица, теткица, школице.

Дискусија уз асоцијације и саме асоцијације потврдиле су да метафора (сличност по облику, боји, функцији и сл.) и полисемија 
свакако јесу у основи лексикализације именичких деминутива. Тако се на основу степена лексикализованости може утврдити статус свих постојећих лексикализација именичких деминутива у српском језику, поготово асоцијативном методом, коју смо користили.

Када се пореде степен лексикализованости и прве асоцијације матерњих говорника, заиста постоји тенденција да код лексикализованих деминутива са потпуно довршеним процесом лексикализације прва асоцијација буде у вези са лексикализованим значењем. Уз изузетке, истичемо и да је проценат остварене лексикализоване употребе на нивоу реченица које су смишљали испитаници и онда када су писали прве асоцијације на лексеме-стимулусе врло сличан, што упућује на стабилност перцепције првог значења одговарајућег именичког деминутива као лексикализованог. Изузетке објашњава постојање синонимних термина, нпр. курсор уместо стрелица, богиње уместо козице, микрофон уместо бубица или пак бирања употребе парафразе у говору/писању.

У вези са статусом лексикализованих именичких деминутива у речнику, могло би се размотрити да у речнику посебне одреднице чине они примери код којих се архисема и сфера употребе разликују код лексикализованих и нелексикализованих значења, поготово код лексикализованих множинских облика (щколице, гљивицее и сл.). Услов би био да се ради о потпуној лексикализованости и да прва асоцијација упућује на лексикализовано значење. Алтернатива томе била би да, уколико се деминутивно и лексикализовано значење налазе у оквиру исте одреднице (уколико је, на пример, јака метафоричка веза), треба размотрити да се системски прво наводи лексикализовано значење уколико је фреквентније (као што је већ учињено у одредницама бабица и водиц̧а).

\section{ЛИТЕРАТУРА}

Драгићевић, Р. (2008). Творбени и семантички статус једног значења именица типа ручица [Derivational and Semantic Status of the Nouns Like ručica]. Српски језик, XIII/1-2, 203-213.

Драгићевић, Р. (2010). Вербалне асоиијаиије кроз српски језик и културу [Verbal Associations Across Serbian Language and Culture]. Београд: Друштво за српски језик и књижевност Србије.

Драгићевић, Р. (2016). Лексикализација (на примеру именичких деминутива) [Lexicalization (in the Noun Diminutive Examples)]. У Ј. Дражић, И. Бјелаковић, Д. Средојевић (Ур.), Теме језикословне у србистици кроз дијахронију и синхронију, зборник у част Љиљане Суботић (стр. 453-463). Нови Сад: Филозофски факултет у Новом Саду.

Đurić, R. (2004). Deminutivni sufiksi u srpskom i njihovi prevodni ekvivalenti u engleskom jeziku [Diminutive Suffixes in Serbian and Their Equivalents in English]. Zbornik Matice srpske za filologiju i lingvistiku, 47/1-2, 147-164. 
Грицкат, И. (1995). О неким особеностима деминуције [About Some Aspects of Diminution]. Јужнословенски филолог, LI, 1-30.

Hohenhaus, P. (2005). Lexicalization and Institutionalization. In Stekauer, P., R. Lieber (Eds.), Handbook of Word-Formation, Studies in Natural Language and Linguistic Theory, vol. 64, 353-373.

Јанић, А. (2012). Критеријуми за идентификацију лексикализованих деминутива у српскоме језику [Criteria for Identifying Lexicalized Diminutives in the Serbian Language]. Годишььк Филозофског факултета у Нишу, 12, 79-88.

Јанић, А. (2013а). Лексикализација именичких деминутива у српскоме језику [Lexicalization of Noun Diminutives in the Serbian Language]. Philologia Mediana, V/5, 367-380.

Јанић, А. (2013б). Однос употребе именичких деминутива и њихових лексикализација у српском језику [The Relation of the Usage of Noun Diminutives and Their Lexicalizations in the Serbian Language]. Годишъак за српски језик Филозофског факултета у Нииу, 13, 241-252.

Јовановић, В. (2010). Деминутивне и аугментативне именице у српском језику [Diminutive and Augmentative Nouns in the Serbian Language]. Београд: Институт за српски језик САНУ.

Клајн, И. (2003). Творба речи у српском језику [Word Formation in the Serbian Language]. Књ. 2. Београд: Институт за српски језик САНУ, Завод за уџбенике и наставна средства, Нови Сад: Матица српска.

Макишова, А. (2006). Деминутиви у словачком и српском језику [Diminutives in Slovak and Serbian]. У М. Клеут (Ур.), Сусрет култура, 4. Међународни научни симпозијум, (стр. 609-617). Нови Сад: Филозофски факултет у Новом Саду.

Николић, М. (Ур.). (2000). Обратни речник српскога језика [The Inverse Dictionary of the Serbian Language]. Нови Сад: Матица српска, Београд: Институт за српски језик САНУ.

Николић, М. (Ур.). (2007). Речник српскога језика [The Dictionary of the Serbian Language]. Нови Сад: Матица српска.

Peco, A., Ž. Stanojčić (Ur.). (1972). Enciklopedijski leksikon Mozaik znanja: Srpskohrvatski jezik [Encyclopedic Lexicon the Mosaic of Knowledge: the SerboCroatian Language]. Tom 1. Beograd: Interpres.

Пипер и др. (2005). Асочијативни речник српскога језика [The Associative Dictionary of the Serbian language]. I део. Београд: Београдска књига, Службени гласник СЦГ, Филолошки факултет у Београду.

Радић, П. (1997). О деривационом аспекту речничког богаћења: Нормативистички приступ [About the Derivational Aspect of Lexicon's Corpora: The Normativistic Aspect]. Језик данас, 1, Нови Сад, 22-24.

Tafra, B. (2005). Leksikalizacija kao leksikološki i leksikografski problem [The Lexicalization as a Problem of Lexicology and Lexicography]. U Tafra, B. Od riječi do rječnika [From a Word to the Dictionary]. (str. 115-123). Zagreb: Školska knjiga. 


\title{
ASSOCIATIVE APPROACH TO LEXICALIZED NOUN DIMINUTIVES WITH THE DERIVATIONAL SUFFIX -ICA FROM THE PERSPECTIVE OF THE STUDENTS OF THE SERBIAN LANGUAGE AND LITERATURE
}

\author{
Aleksandra A. Janić \\ University of Niš, Faculty of Philosophy, Serbian Language Department, Niš, Serbia
}

\section{Summary}

The subject of this paper is lexicalized noun diminutives with the Serbian derivational suffix -ica from the perspective of cognitive linguistics. The lexemes which are used in the questionnaire as stimuli and associations for Serbian native speakers are considered regarding whether those diminutive forms are mainly connected to a lexicalized meaning or not. In the group with the dominant lexicalized usage there are: babica, bojica, bombica, vodica, gljivice, jabučica, jagodica, kartica, knjižica, kolica, korpice, košuljica, krpice, krunica, maramica, papučica, pločica, pogačica, posteljica, puškica, resica, tetkica, školice, and in the group with the dominant non-lexicalized usage there are: bubica, glinica, žabica, zvezdica, jelkica, kesica, kobilica, kozice, lepezica, lopatica, ogradica, pahuljice, svećica, strelica, čašica, četkica.

With some exceptions, the percentege of the lexicalized usage of diminutives in a sentence and their associations is very similar, which shows the stability of the perception of the first associaton to the meaning of the diminutive noun form. The mentioned exceptions are usually those which have a non-diminutive synonym, such is the case in the following pairs: kursor-strelica 'cursor', boginje-kozice 'smallpox', mikrofon-bubica 'microphone' or those for which lexicalized meaning is also paraphrased and used as such.

The most numerous associations were nouns, then adjectives and noun phrases, sentences, verbs, and lastly adjective phrases. The result of this research has shown that there are clear tendencies regarding the lexicalized usage of noun diminutive forms in Serbian. Furthermore, the lexicalized usage of a noun diminutive form is in corelation with the level of lexicalization, as well as with the frequency of usage and its familiarity to the speakers. The analyzed data should also be considered in lexicography, because the fullylexicalized diminutives could be treated separately, not always in relation with their diminutive form, which is more obvious when archiseme is different in non-lexicalized and lexicalized meaning (e.g. babica 'grandmother_Dim' accoucheuse) or the lexicalized meaning should consistently be the first one when treated together with the diminutive one. 